\title{
MEMELIHARA SEMANGAT PERSATUAN DAN KESATUAN
}

\author{
Nama:Laila yolanda putri aryanti \\ Nim :2161B0034 \\ Lailayolanda902@gmail.com
}

\begin{abstract}
Abstrak
Negara kesatuan republik Indonesia (NKRI) menghimpun keseluruhan wilayah,suku bangsa, dan budaya.Indonesia sebagai kepulauan yang besar memiliki wilayah dari sabang sampai marauke. Untuk menjaga keutuhan bangsa yang majemuk ini,dibutuhkan persatuan dan kesatuan yang kuat, seperti yang di amanatkan dalam sila ketiga pancasila.Mengapa perlu adanya pembahasan tentang persatuan dan kesatuan adalah untuk mengingatkan kembali bahwa tanpa adanya persatuan dan kesatuan yang di jalin oleh masyarakat Indonesia maka sulit akan adanya keharmonisan dalam berkehidupan berbangsa dan bernegara.Memelihara persatuan dan kesatuan juga perlu ada campur tangan pemimpin dalam membuat kenyamanan atau keutuhan untuk masyarakat dengan itu pemimpin harus tau betul keadaan masyarakat.
\end{abstract}

\section{Latar Belakang}

Indonesia merupakan negara yang besar yang wilayahnya terjarak oleh pulau-pulau yang luas dan banyak maka itu Indonesia memiliki ciri khas yaitu keanekaragaman budaya,adat istiadat,agama, suku dan bahasa.Persatuan dan Kesatuan merupakan kunci suatu negara dalam membangun suatu bangsa,tanpa adanya persatuan serta kesatuan yang dijaga oleh negara maka keadaan suatu negara mudah di goyah oleh berbagai ancaman baik dari luar negri maupun ancaman dalam negri yang menjadi bahaya adalah ketika ada ancaman yang disebabkan oleh dalam negri atau bangsa sendiri. Maka itu masyarakat Indonesia sebagai bagian dari warga negara harus mengerti betul arti penting persatuan serta kesatuan demi menjaga keutuhan negara. Terlebih dahulu negara Indonesia adalah negara yang di kenal akan keanekaragaman suku,budaya dan bahasa,yang kapan saja bisa di goyah oleh beberapa isu terutama isu SARA dan ujaran kebencian yang akhir-akhir ini menjadi perbincangan serius di Indonesia yang menjadi salah satu penyebab perpecahan antara warga negara Indonesia di tambah lagi berita-berita kebohongan yang menyebar di kelas anak muda 
dalam jaringan sosial media Internet.

Adapun prinsip-prinsip yang akan di tampakkan dalam kehidupan sehari-hari seperti prinsip Bhineka tunggal ika,prinsip kebesasan sama jawab,prinsip wawasan nusantara dan persatuan pembangun untuk mewujudkan cita-cita reformasi dan wujud kewarganegaraan sebagai pencerminan komitmen terhadap keutuhan Nasional.

\section{Rumusan Masalah}

Berdasarkan latar belakang yang ada,maka dapat di tarik suatu rumusan masalah yaitu sebagai berikut:

1).apa pengertian dari kesatuan?

2).apa saja prinsip-prinsip persatuan dan kesatuan dalam kehidupan sehari-hari ?

3).bagaimana partisipasi masyarakat kewarganegaraan sebagai pencerminan komitmen terhadap keutuhan Nasional ?

\section{Tujuan Penulisan}

Tujuan penulisan ini adalah untuk memberikan wawasan tentang persatuan dan kesatuan demi terbentuknya negara yang harmonis serta mengimplimentasikan dalam kehidupan sehari-hari sebagai bentuk partisipasi secara langsung serta bentuk kepedulian dalam membentuk sikap toleransi,saling menghargai dan menghormati.

\section{Pembahasan}

Pendidikan karakter telah menjadi perbicaraan yang serius di banyak kelas.Pendidikan karakter merupakan salah satu cara untuk meningkatkan kecintaan terhadap negara sendiri merupakan hal yang penting dalam membangun karakter anak-anak muda untuk dapat mencintai negara nya. Mengapa banyak di perbincangan perlu di ketahui bahwa tidak yakin suatu bangsa adalah Masyarakat itu sendiri,maka itu penting nya pendidikan karakter yang perlu diberikan sebagai bekal Pengetahuan bagi masyarakat terutama anak-anak muda yang masih mengenyam pendidikan agar Mengetahui penting nya pendidikan karakter yaitu untuk membentuk sifat yang baik,meningkatkan Kepedulian atas sesama,membangun sifat kepemimpinan.

Memelihara persatuan dan kesatuan juga perlu ada campur tangan pemimpin dalam membuat Kenyamanan atau keutuhan untuk masyarakat dengan itu pemimpin harus tau betul keadaan 
masyarakat.

\section{-Pengertian Bhineka tunggal ika}

Menyusul lambang bangsa Indonesia yang itu arti bahwa bangsa Indonesia adalah negara yang Beragam akan kebudayaan,dan adat istiadat,kata-kata Bhineka tunggal ika terdapat pada lambang Negara Republik Indonedia yaitu burung Garuda Pancasila. Di kaki burung garuda pancasila Mencengkram sebuah pita yang terbaru Bhineka tunggal ika .Kata-kata tersebut dapat pula di artikan:berbeda-beda tetapi tetap satu.

Adapun prinsip-prinsip persatuan dan kesatuan yang harus di hayati serta di mengerti lalu di amalkan dalam kehidupan sehari-hari.

1).Prinsip Bhineka tunggal ika

Mengetahui bahwa kita adalah warga negara Indonesia,yaitu bangsa yang terdiri dari beberapa keragaman,yang menjadi identitas negara sebagai suatu ciri suatu negara, adanya keanekaragaman itu harus kita akui sebagai rasa untuk memupuk persatuan dan kesatuan Indonesia.

2).Prinsip kebebasan yang baru jawab

Warga negara Indonesia memiliki hak kebebasan,termasuk hak untuk menyampaikan Tetapi menyampaikan pendapat tidak dengan kebebasan dengan sebebas bebasnya tetap ada aturan yang harus di patuhi dan di taati bahwa kebebasan juga harus ada tanggung jawab setiap hal yang dilakukan tak lepas dari tanggung jawab.

3).Prinsip wawasan nusantara

Dengan semangat nusantara itu,kedudukan manusia Indonesia di tempatkan dalam Kerangka kesatuan politik sosial,budaya,ekonomi,serta pertahanan keamanan,dengan wawasan itu manusia Indonesia merasa satu,senasip,sepenanggung,sebangsa dan setanah air,serta memiliki satu tekad dalam mencapai cita-cita.

4).Prinsip persatuan pembangunan untuk mewujudakan cita-cita reformasi Dengan persatuan yang telah di bangun oleh pahlawan-pahlawan yang telah berjasa dengan penuh peluh berkeringat dan taruhan nyawa maka tugas masyarakat Indonesia sekarang ini adalah waktu yang tepat untuk bagaimana menciptakan cita-cita yang sudah di cita-citakan pahlawan untuk hidup merdeka bebas dari ancaman dan dapat mengambangkan negara ke arah yang lebih baik. 


\section{Kesimpulan}

Indonesia sebagai negara kepulauan yang besar memiliki wilayah dari sabang sampai marauke. Mengapa perlu adanya pembahasan tentang persatuan dan kesatuan adalah untuk mengingatkan kembali bahwa tanpa adanya persatuan dan kesatuan yang di jalin oleh masyarakat Indonesia maka sulit akan adanya keharmonisan dalam kehidupan berbangsa dan bernegara. oleh karna itu persatuan dan kesatuan adalah unsur yang harus di bangun oleh warga negara dalam meningkatkan rasa persaudaraan,rasa menghormati,rasa menghargai,demi menjaga keharmonisan negara.

Persatuan dan kesatuan tidak hanya di bangun oleh warga negara sebagai masyarakat yang menghuni suatu wilayah tapi juga di bangun oleh pemerintah sebagai wakil rakyat yang mewakili seluruh suara rakyat demi terciptanya kehidupan yang nyaman, maka itu perlunya sikap saling bahu membahu antara masyarakat dan pemerintah dalam membangun negara ini,membangun perekonomian, pendidikan,kesehatan dan lain-lain.

\section{Daftar Pustaka}

Japar,Muhammad,'PENGEMBANGAN MODEL PENDIDIKAN KARAKTER BERWAWASAN KEBANGSAAN DI PERGURUAN TINGGI',2017.

Kewarganegaraan, pendidikan pancasila,dan kelas VII. jakarta:kebudayaan,kementerian pendidikan,2019.

Siregar,Septi mulyani,and Nadiroh,'Peran keluarga dalam menerapkan nilai budaya suku Sasak dalam memelihara lingkungan', Jurnal Green Growth Dan Manajeman Lingkungan,5(2016),28-40. 